\title{
Mindfulness kan beter uit de zorg verdwijnen
}

Veel mensen en zeker de kwetsbaren missen in deze tijd aandacht van hun naasten, vrienden en familie. Een veel gehoorde ervaring in de klinische praktijk is dat er in de sociale contacten van degenen die hulp vragen weinig aandacht voor hen is, iedereen is druk en loopt achter diens eigen doelen aan. Wat er resteert aan onderlinge contacten wordt als vluchtig en oppervlakkig ervaren. De tijd die mensen voor een goed gesprek met vrienden vrij maken en de echte aandacht die ze voor de ander in deze tijd kunnen opbrengen, lijken met het verschuiven van het accent van hechting naar narcisme vermindert. Het tempo waarin ons leven zich voltrekt als gevolg van de ICT-revolutie, de dominantie van de marktwerking, informatie overload en de snelheid waarmee we ons kunnen verplaatsen, is nieuw in de geschiedenis. De buitenwereld is vele malen uitdagender geworden dan in de jaren vijftig van de vorige eeuw. Het gesprek dat toen bij het houtvuur op gang kon komen, is nu niet erg kansrijk meer. In sociale conversaties stapelen mensen hun eigen verhalen doorgaans naast elkaar zonder dat er dwarsverbindingen in de communicatie ontstaan. Op die momenten lijken mensen vooral uitstootmachines. Onze samenleving is toenemend een kenniseconomie geworden en daarmee veel complexer en meer afhankelijk van mentale arbeid. In veel bedrijven en organisaties zijn de werkers het kapitaal geworden in plaats van de productiemiddelen van vroeger. De grenzen tussen werk en privé zijn door de sociale media praktisch verdwenen. Aan de binnenkant - de intrapsychische architectuur - zijn mensen de laatste 35 jaar meer en sneller veranderd dan in lange, trage tijd daarvoor. De schildpad als icoon van de evolutie heeft de hogesnelheidstrein genomen. We zijn veel beter opgeleid, de cognitieve processen en patronen die generaties lang leken te slapen, zijn ontwaakt en actief geworden. Cognitieve intelligentie stijgt nu elke tien jaar ongeveer 6 IQ-punten. Er zijn nu voor het eerst evenveel hoog- als laagopgeleiden in Nederland, dit zit in de buurt van 28 procent, 35 jaar geleden cirkelde het percentage hoogopgeleiden rond de 5 procent. Behalve beter opgeleid zijn we assertiever, extraverter en narcistischer geworden. De druk op individuele beslissingen, de noodzaak uit veel meer mogelijkheden te kiezen dan wat comfortabel is, namelijk drie of vier alternatieven, heeft mede geleid tot een nieuwe vorm van psychische stress.

Theodore Millon is nu ruim een jaar geleden overleden. In Nederland kennen de psychologen hem slecht, aan de Vrije Universiteit van Brussel gaven we hem een eredoctoraat. Zijn werk op het thema persoonlijkheid en persoonlijkheidsstoornissen is onovertroffen. Ondermeer beschrijft hij drie dimensies werkzaam in de persoonlijkheid: actief - passief, plezier - pijn, zelf - ander. Voor nu gaat het alleen over de dimensie actief - passief. Voor een gezond psychisch evenwicht is het in deze theorie essentieel dat we kunnen genieten van actief zijn en dit op tijd kunnen afwisselen met genieten van passiviteit (lui zijn?). Diagnostisch gezien onderzoek je dit door iemand bijvoorbeeld te vragen of hij kan genieten van een strandvakantie en dan echt liggen en niks doen. Niksen betekent ook de binnenwereld naar boven durven laten komen en daarvan genieten, in plaats van in de actie schieten en in de buitenwereld gaan wegpoetsen (velen gaan op zo'n moment stofzuigen) wat van binnen aan fantasie en emotie dreigt op te duiken. Het onvermogen passief te zijn en daarvan te kunnen genieten is passend en kenmerkend voor veel mensen in deze tijd. Velen bewegen actief richting hun burn-out, fibromyalgie, rugklachten, depressie en paniekstoornis. Die klachten dwingen deze actieve veeldoeners weer tot passief zijn en zo herwinnen ze een verloren evenwicht, echter wel getooid met klachten. Maar onze cultuur produceert hier gelukkig oplossingen voor. Eén ervan is de golf van mindfulness die de laatste jaren weldadig over ons heen is gespoeld. Het opmerkelijke is dat psychotherapeuten, psychologen en psychiaters mindfulness actief zijn gaan beheren, onderzoeken en als (onderdeel van hun) behandeling zijn gaan opdienen aan hun patiënten en tevens deze activiteit zijn gaan declareren bij zorgverzekeraars. In plaats van mindfulness te zien als een cultuurverschijnsel en daarmee als een gezonde sociaalculturele reactie op het neurotische overactief zijn van onze tijd, domesticeren ze deze activiteit en trachten deze onder te brengen in de psychotherapie. Zeer onverstandig, want daarmee verwatert de psychotherapie en wordt deze culturele ontwikkeling geremd. Bij verwatering van psychotherapie is psychotherapeut noch patiënt gebaat. De activiteit waarmee mindfulness overigens wordt toegeëigend door deze collega's lijkt verdacht veel op het onvermogen passief te zijn en dus typisch passend in de neurotische trekken van onze cultuur.

Prof. dr. J.J.L. Derksen is klinisch psycholoog en hoofdredacteur van GZ-Psychologie. 